\title{
The Legal Responsibility of The Counselor on The Basis of Counseling Contract
}

\author{
Mustafa Alper Gümüş*, Aynur Eren-Gümüş ${ }^{* *}$
}

\begin{abstract}
The subject of this study is the legal responsibility of counselor in the extent of its legal dimension of counseling relation. First, the relationship between the professional responsibility based on the ethic codes and the legal responsibility of counselor has been explained; then, in the framework of the contract which forms the basics of the contractual responsibilities of counseling, the obligations of the counselor and the client, and the lawful conditions and their results from the arrangement of the contract to its termination, and the responsibilities of the counseling centers have been focused on as it is embodied in the Articles 386-389 of The Turkish Code of Obligations for a contract for counseling arranged as a procuracy. In addition, confidentiality is crucial issue for the counselors, the related articles of the Turkish Penal Code have been held.
\end{abstract}

Key Words: Legal responsibility of counselor, counseling contract.

\footnotetext{
*Assoc. Prof. Dr. Yeditepe University, Faculty of Law, malpergumus@ hotmail.com.

** Assist. Prof. Dr. Maltepe University Faculty of Education, aynurgumus @ hotmail.com
} 


\section{SUMMARY}

In this article, the legal dimension of the relationship of psychological service between the counselor and the client, and the liability arising from the Private Law Provisions have been held as a special subject.

The immediate solutions to the concerns of the service of psychological counseling and guidance, which has been still making progress in our country's conditions, are to maintain execution under the rules of a professional association which is united in the form of a public establishment to regulate the ethical codes in accordance with the professional sanctions based on legal sources.

Although, due to non-existence of such a professional association, counselors are not subject to professional penalty, yet, in case of transgression of the professional ethical codes they have an obligation to exercise due diligence regarding the psychological counseling contract which is made by the parties based on the Articles between 386-398 of the Turkish Code of Obligations, and abide by the terms of this contract.

Counselor's main liability incurred from Psychological Counseling Contract (PCC) is as follows: To solve the psychological problems of the client with due diligence; to perform counseling service individually in its duration; to be loyal to the counseling service: efficient information exchange, respect the confidentiality; to record the counseling settings and keep those records; to protect the interest of integrity of the client.

On the other hand, the liability of the client is to retain the counselor, and to protect the interest of integrity of the counselor.

Due to the liability which PCC incurs, counselor, is liable to make amends for a pecuniary loss and intangible damages resulting from the breach of a contract by a wrongful act.

For any justified or unjustified reason either of the parties may terminate PCC at any time; counselor may resign, client may discharge the counselor. However, the parties are obliged to use their right to revoke the contract at an appropriate time, otherwise they are liable to indemnify for the damages that the other party suffers.

If the counseling has been performed by the counselors who are working in a Psychological Counseling Center, counselor is the agent who is fulfilling the liability of the Center. Hence, the center is responsible for the wrongful acts of the counselor, whereas the counselor is responsible for wrongful acts not for the liability incurred from PCC.

Although this study has been related to legal responsibility of the counselor on the basis of counseling contract confidentiality is also crucial issue for the counselors, the articles 50, 98, 133, 136, 137, 239, 278 and 280 of the Turkish Penal Code have been held as well.

There is a consistency between the ethical codes set for Psychological Counseling and Guidance and the subject of this study, the legal liability of counselors for the clients. 


\title{
Psikolojik Danışmanın Psikolojik Danışma Sözleşmesine Dayalı Hukuksal Sorumluluğu
}

\author{
Mustafa Alper Gümüş ${ }^{*}$, Aynur Eren-Gümüş ${ }^{* * *}$
}

ÖZ. Bu çalışmanın konusunu, psikolojik danışma ilişkisinin hukuksal boyutu kapsamında psikolojik danışmanın psikolojik danışma sözleşmesine dayalı hukuksal sorumluluğu oluşturmaktadır. Önce psikolojik danışmanın etik kurallara dayalı mesleki sorumluluğu ile hukuksal sorumluluğu arasındaki ilişki açıklanmış; sonra da kuruluşundan sona ermesine kadar, psikolojik danışmanın sözleşmeye dayalı sorumluluğunun temelini oluşturan Borçlar Kanunun m.386-398. maddeleri arasında düzenlenen vekalet sözleşmesi niteliğindeki psikolojik danışma sözleşmesi ele alınmıştır. Yine bu sözleşme çerçevesinde psikolojik danışmanın ve danışanın borçları, psikolojik danışmanın hukuksal sorumluluğunun şartları ve sonuçları ile psikolojik danışma merkezlerinin sorumluluğu da incelenmiştir. Ayrıca, bu çalışmanın kapsamına danışmanın sır saklama yükümlülügü genel olarak Türk Ceza Kanununun ilgili maddelerine göre ele alınarak açıklanmıştır.

Anahtar Sözcükler: Psikolojik danışmanın hukuksal sorumlulukları, psikolojik danışma sözleşmesi.

\footnotetext{
* Doç Dr. Yeditepe Üniversitesi Hukuk Fakültesi, malpergumus@hotmail.com *** Yrd. Doç. Dr. Maltepe Üniversitesi Eğitim Fakültesi, aynurgumus@ hotmail.com

$\mathrm{Bu}$ çalıșmanın daha kapsamlı bir içerik kazanmasında değerli önerilerinden yararlandı̆̆ımız Ege Üniversitesi Eğitim Fakültesi, Rehberlik ve Psikolojik Danışmanlık Anabilim Dalı Başkanı sayın Prof. Dr. Süleyman Doğan'a ve Türk Ceza Kanunu'na ilişkin açıklamaların uygunluğunu değerlendiren Marmara Üniversitesi Hukuk Fakültesi Ceza Hukuku Anabilim Dalı öğretim üyesi sayın Doç Dr. Ayşe Nuhoğlu'na teşekkür ederiz.
} 


\section{GíRIŞ}

Psikolojik danışma hizmetleri, başta ABD'de ve bazı gelişmiş Avrupa ülkelerinde eğitim kurumlarından özel psikolojik danışma hizmetlerine kadar yaygın ve etkili bir hizmet alanı olarak kabul edilmektedir. Ülkemizde 1950'li yıllardan başlayarak eğitim sistemimiz içinde tamamlayıcı bir hizmet olarak varolan psikolojik danışma ve rehberlik hizmetleri, bir yandan eğitim alanında, bir yandan da sağlık kurumları dahil farklı kurumlarda iyileştirici, önleyici ve geliştirici psikolojik hizmetler olarak gelişimini devam ettirmektedir. Ancak ülkemiz koşulları içinde psikolojik danışma hizmet alanının meslekleşme yolunda çözüm bulması gereken önemli sorunları vardır ve bu sorunlar arasında psikolojik danışma ve rehberlik hizmetleri için belirlenen etik kuralların (TÜRK PDR-DER, 1995; 2006) yasa kaynaklı mesleki yaptırımla desteklenmemesi sorunu da bulunmaktadır.

Psikolojik danışma hizmetleri ilk olarak verilmeye başlandığı yıllarda, deneyimsiz ve genç öğrencilere neyi, nasıl yapmalarının daha iyi olacağını söyleme, öğüt verme ya da yol gösterme odakl1, profesyonel olmayan uygulamalar biçimindeyken, 1940'lardan sonra ABD'de psikoloji ve sosyal çalışma alanlarının yanında kendine özgü, profesyonel bir psikolojik yardım mesleği olarak kabul edilmeye başlandı (Patterson ve Eisenberg, 1983). Profesyonel düzeyde verilmeye başlanan psikolojik danışma hizmetleri özellikle gelişim, uyum ve karar verme ile ilgili önemli sorunlara yönelik önleyici ve iyileştirici işlevlerini yerine getirirken, profesyonel davranışları kurallara bağlayan, mesleğe özgü etik kuralların da belirlenmesi zorunluluğunu doğurdu.

Psikolojik danışmanların uymakla yükümlü oldukları etik kuralların kişisel doğru-yanlış yargılarına ve tercihlerine bırakılmaksızın yasal yaptırımlarla da güçlendirilmesi bir gereklilik olarak görüldü. Çünkü tek başına etik kuralların profesyonel davranışların ortaya çıkmasını sağlayıcı ve denetleyici gücü olmadığı gibi, bu kurallar psikolojik yardım elemanlarının hukuksal sorumluluğunun belirleyicisi de olamazlar (Bersoff, 2002).

Yayınlanan Yargıtay kararları incelendiğinde, Türk Hukuk uygulamalarında 90'lı yilların sonundan itibaren hekimlerin sorumluluğuna yönelik tazminat davalarında bir patlama yaşandığı görülürken, aynı zamanda hekim olan psikiyatristlere karşı açılmış bu tür davalara rastlanılmamıştır. Doğaldır ki psikolog ve psikolojik danışmanların sorumluluğuna yönelik davalarla da henüz karşılaşılmamıştır. $\mathrm{Bu}$ durum söz konusu meslek gruplarının "hukuksal sorumluluklarının olmaması" ile değil; öncelikle bu yardım hizmetlerinden yararlanan bireylerin hukuksal haklarına ilişkin önemli düzeydeki bilgi eksikliği ile açıklanabilir. Ruh sağlığı hizmetlerinin hukuksal boyutuna ilişkin bilgi eksikliği sadece bu hizmetlerden yararlanan bireyler için değil, bu yardımı veren uzmanlar için de geçerlidir. Psikolog ve psikolojik danışmanlar uygulamalarında yasal sorumlulukları olmadığı düşüncesiyle, sadece mesleki etik standartları sınırlayıcı ve düzenleyici olarak görmekte ve rahat davranmaktadırlar. Oysa hukuk düzeni genel bir biçimde bütün kişisel ve profesyonel (mesleki) iş görme faaliyetlerini kapsayacak sorumluluk hükümlerini de içermektedir. 
Bu çalışmada "özel” psikolojik danışma hizmetlerinde psikolojik danışman ile danışan arasındaki psikolojik yardım ilişkisinin hukuksal boyutu ve psikolojik danışmanın "özel hukuktan" doğan hukuksal sorumluluğu ele alınmış olup; kamusal hizmet olarak yürütülen psikolojik danıșma hizmetlerine ilișkin idare hukuku kaynaklı sorumluluk bu çalışmanın dışında bırakılmıştır. Bu incelemede yer alan sözleşmeye dayalı sorumluluk kuralları, psikologların sorumluluğu bakımından da uygulama bulacaktır.

Psikolojik Danışmanın Sözleşmeye Dayalı Sorumluluğu ile Mesleki Sorumluluğu Arasındaki Ayırım

Türkiye'de psikolojik danışmanların yasal dayanak eksikliği nedeniyle bir "kamu kurumu niteliğinde meslek kuruluşu (meslek odası)" çatısı altında örgütlenmemiş olması, hukuksal olarak sorumlu olmayacakları anlamına gelmez. Psikolojik danışmanlar, mesleki faaliyette bulunmak için üye olmalarını zorunlu kılacak ve mesleki yaptırımları uygulayacak meslek birliklerinin henüz oluşturulmamasına bağlı olarak, mesleki statülerinden kaynaklanan yükümlülükler niteliğini taşıyan (Sungurtekin-Özkan, 1999) mesleki etik kuralları ihlal etmeleri durumunda mesleki yaptırımlara uğramasalar bile; Borçlar Kanununun hükümleri çerçevesinde danışana karşı hukuken sorumludurlar. Ancak, psikolojik danışmanlar tarafından meslek disiplini ve ahlâkının korunması için Anayasanın 135. maddesinde düzenlendiği gibi "kamu kurumu niteliğindeki meslek kuruluşu" özelliğine sahip bir meslek birliğine bağlı olarak psikolojik danışma hizmetlerini yürütmeleri bir zorunluluk olarak görülmelidir. $\mathrm{Bu}$ zorunluluğun gereği olarak Türkiye'de psikolojik hizmetler alanında bir meslek birliğinin kurulmasına (Acar, 2003); ABD ve Avrupa ülkelerinde olduğu gibi psikolojik hizmetlerin yürütülmesine ilişkin ilkeleri ortaya koyan yasal düzenlemelere acilen ihtiyaç vardır.

Etik kural ve standartlar, psikolojik yardım alan insanları korumayı ve psikolojik yardım sunan profesyonel elemanları denetlemeyi hedeflerken, bunu garanti edemeyeceği (Doğan ve Ergüner-Tekinalp, 2002) gibi, yasa destekli olmamaları da bu hedefin gerçekleşmesini büyük ölçüde sınırlar. Örneğin bir psikolojik danışmanın, danışanına tecavüz girişiminde bulunmasının "cezai sorumluluğu" yanında "sözleşmeye dayalı sorumluluğuna" da yol açacağı ve kendisi bir yandan ceza hukuku yaptırımı olan hapis cezası ile cezalandırılırken, diğer taraftan sözleşme ihlalinin yaptırımı olarak danışanın uğradığı zararlarını karşılamak için tazminat ödemek zorunda kalacağı açıktır. Ancak bu psikolojik danışmanın, aynı zamanda etik kuralların ihlali nedeniyle de "meslekten ihracı" gerektiği halde; bu yönde mesleki-idari yaptırımı belirleyip uygulayacak "yetkili" bir meslek birliği olmadığından, hapisten çıktıktan sonra psikolojik danışman olarak mesleğinde faaliyette bulunmasına ve aynı şekilde danışanlarına zarar vermesine engel olunamayacaktır.

Sonuçta, psikolojik danışma yardımının profesyonel ilkeler çerçevesinde verilmesi ve böylece yardım alan kişilerin korunması psikolojik danışmanların sözleşmeye dayalı ve cezai sorumluluk kuralları yanında, yaptırımlarla desteklenmiş mesleki kurallara tabi olması ile gerçekleştirilebilir. Bu nedenle, psikolojik danışma 
ve rehberlik alanında geçerli olan etik kurallar, yasal dayanağa sahip, -para cezasından, geçici ve/veya sürekli mesleki faaliyetten uzaklaştırmaya kadar uzanan"mesleki yaptırımlarla" desteklenmedikçe "gerekli" yaptırım gücünden yoksun olacaktır. Ancak söz konusu etik kuralların, "çoğunlukla psikolojik danışmanın sözleşmeye dayalı yükümlülükleriyle örtüştügüu” ve "özenli” bir psikolojik danışma sürecinin gereklerini ortaya koyarak psikolojik danışmanın kusurunun tespitinde belirleyici işlev gördüğü açıktır.

Yukarıdaki açıklamaların ortaya koyduğu üzere, psikolojik danışmanın sorumluluğu üç temel kaynağı dayanmaktadır: 1. Psikolojik danışmanın etik kurallara dayalı mesleki sorumluluğu, 2. Psikolojik danışmanın borçlar hukuku kapsamında sözleşme kurallarına dayalı sorumluluğu, 3. Psikolojik danışmanın ceza hukuku kurallarına dayalı cezai sorumluluğu. Bu üç sorumluluk temelinden birincisini oluşturan etik kurallara dayalı mesleki sorumluluğun yaptırıma bağlanamamış olması karşısında, Türk Hukukunda psikolojik danışmanın sorumluluğu diğer iki sorumluluk temeli üzerinden yapılandırılır. Bu çalışmanın esas amacı psikolojik danışmanın sözleşmeye dayalı sorumluluğunu ortaya koymaktır. Psikolojik danışmanın cezai sorumluluğu kural olarak incelememiz dışında yer almasına rağmen, psikolojik danışmanlar için özel önem taşıyan ceza hukuku hükümlerine de kısaca değinilmiştir.

\section{Psikolojik Danışma Sözleşmesinin Hukuksal Niteliği}

Psikolojik danışman ve danışan arasında kurulan bir hukuksal ilişki olarak psikolojik danışma sözleşmesi (PDS), Borçlar Kanununun (BK) 386. ve 398. maddeleri arasında düzenlenen "vekalet sözleşmesinin" bir görünümü olarak karşımıza çıar. Vekalet sözleşmesi BK'da yer alan sözleşmeye ilişkin yapısal unsurların bir araya getirilmesiyle şu şekilde tanımlanabilir: Vekalet sözleşmesi öyle bir sözleşmedir ki, vekil, müvekkil ile arasındaki özel güven ilişkisine dayalı biçimde, müvekkilin menfaatine ve hesabına olarak ve nispeten yersel, zamansal ve maddi bağımsızlık içerisinde bir işi, ücretsiz veya sözleşmede kararlaştırılmışsa ya da adet varsa ücretli olarak görmeyi borçlanır (Gümüş, 2001). Bu çerçevede psikolojik danışman "vekil", danışan "müvekkil" konumundadır1 .

Bu bağlamda PDS, öncelikle bir özel hukuk sözleşmesi olup, eşit ilişkideki taraflar arasında özel hukuk kurallarına göre sonuç doğurur. Ancak karşılıklı yükümlülüklerin ağırlığı bakımından PDS, ana baba-çocuk ilişkisinde olduğu gibi temelde asimetrik bir ilişki kurar ve bu ilişkide temel ağılık psikolojik danışmanın üzerindedir (Petermann, 2003).

PDS bir borç sözleşmesidir. Bu sözleşmenin kurulmasıyla asli olarak psikolojik danışman danışana karşı onun psikolojik sorunlarının çözümüne yönelik profesyonel düzeyde faaliyette bulunmayı borçlanırken; danışan da psikolojik danışmanın

\footnotetext{
${ }^{1}$ Hukuk alanındaki Türkçe kaynaklarda "danışan" ve "psikolojik danışman” kavramları yer almamakta, hukuktaki karşılıkları olan "vekil” ve "müvekkil” kavramları yer almaktadır. Bu çalışmaya kaynak olan hukuki eserlerden yararlanırken "müvekkil" yerine "danışan", "vekil" yerine de "psikolojik danışman” kavramları kullanılarak aktarım yapılmışıır.
} 
problem çözme etkinliğine karşıllk, kararlaştırılan ya da adetin gerektirdiği belirli bir ücreti ödemeyi borçlanır. PDS psikolojik danışmanın problemi çözme yönündeki psikolojik yardımının zamana yayılması nedeniyle de sürekli bir borç ilişkisi niteliğine sahiptir (Gümüş, 2001; Yavuz, 2002).

\section{Psikolojik Danışma Sözleşmesinin (PDS) Kurulması}

Danışan ile psikolojik danışman arasındaki PDS'nin kurulması için tarafların karşılıklı ve birbirine uygun iradelerini açıklamaları yeterlidir. Bu çerçevede "şekil serbestisi" içerisinde sözleşmenin sözlü veya yazılı (Tan, 1992), açı veya örtülü irade beyanları ile kurulması her zaman için mümkündür. Ancak vekalet sözleşmesine ilişkin BK m.387 hükmü çerçevesinde psikolojik danışman, psikolojik danışmanlığı bir mesleki faaliyet olarak yapıyorsa ya da bu türden bir hizmeti vermeyi kabul edeceğini önceden ilan etmişse, danışandan psikolojik danışma ilişkisi kurma talebini "derhal" geri çevirmedikçe, psikolojik danışmanlık yapmayı kabul etmiş sayılır. Buradaki "derhal" ifadesi, "uygun" bir süre olarak değerlendirilir (Gümüş, 2001).

PDS'nin geçerliliği, psikolojik danışman ve özellikle danışanın kendi eylemiyle borç altına girebilme ehliyetine (tam fiil ehliyetine) sahip olmasına bağlıdır. Bu nedenle psikolojik danışman, danışanın ayırt etme gücüne sahip olduğu, ancak ergin olmadığı yani kural olarak on sekiz yaşını tamamlamadığı hallerde PDS'nin geçerli olabilmesi için danışanın yasal temsilcisinin (velayet hakkına sahip ana ve/veya babası ya da vasisinin) onayını almalıdır (Ayan, 1991; Şenocak, 2001).

\section{Psikolojik Danışma Sözleşmesinde Tarafların Borçları}

Psikolojik danışmanın sorumluluğu sözleşmeye dayalı bir kusur sorumluluğudur. Buna göre psikolojik danışman ancak psikolojik danışma sürecindeki, borçlarına ilişkin "kusurlu" sözleşme ihlallerinin (psikolojik danışmanın sözleşmeden doğan borçlarını hiç ya da gereği gibi yerine getirmemesinin) danışana vermiş olduğu zararlardan sorumludur. Psikolojik danışmanın PDS'den doğan borçlarını ihlalindeki kusuru, kast veya ihmal (gösterilmesi gereken özenin gösterilmemesi) şeklinde gerçekleşebilir. Danışan sözleşme ihlalini, uğradığı zararı ve sözleşme ihlali ile uğradığı zarar arasındaki nedensellik bağını; psikolojik danışman ise yasa gereği varsayılan kusurunun olmadığını ispatlamakla yükümlüdür (BK m.96).

\section{Psikolojik danışmanın borçları}

a. Psikolojik danışmanın danışanın problemlerini çözmeye yönelik olarak psikolojik danışma sürecini “özenli” olarak yürütme (faaliyette bulunma) borcu:

Psikolojik danışmanın PDS'den doğan "esas" borcunu, danışanın problemini çözmeye yönelik olarak "özenli" davranması oluşturmaktadır. Danışma sürecinde özensiz davranma, psikolojik danışmanı danışanın uğradığı zararlardan sorumlu kılar. Dolayısıyla psikolojik danışman, psikolojik danışma disiplininin uygulamaları 
bakımından genel kabul gören ilke ve tekniklerine uygun olarak, özenli bir şekilde psikolojik danışma sürecini yürütmek durumundadır.

Vekalet sözleşmesi olarak PDS'de psikolojik danışman, danışana karşı belirli bir sonucu (problemini ortadan kaldırmayı) değil, belirli bir sonuca (problemi çözmeye) yönelik çaba göstermeyi borçlanır. Bu anlamda psikolojik danışman, danışana karşı hiç bir zaman için sonucun gerçekleşmemesinden (problemin ortadan kalkmamasından) dolayı sorumlu değildir. Psikolojik danışman seçtiği ve yürüttüğü özenli psikolojik danışma sürecine rağmen problem çözümü gerçekleşmese de süreci özenli olarak yürütme borcunu yerine getirmiş olur. Ancak, psikolojik danışman danışana karşı belirli bir sonucu ayrıca borçlanmışsa, sonucun gerçekleşmemesinden dolayı, psikolojik danışman bir "garanti sözleşmesi" çerçevesinde danışana karşı sorumlu olur (Petermann, 2003).

Psikolojik danışmanın göstermesi gerekli olan özenin ölçüsü, kural olarak BK m.390 kapsamında "ortalama bedensel, bilişsel, duygusal, sosyal yetilere sahip bir psikolojik danışmanın, mesleğe özgü ortalama davranışıdır". Dolayısıyla objektifleştirilmiş ölçütlerle ortalama bir psikolojik danışmanın bilgi, yetenek ve niteliklerine sahip olmadan psikolojik danışmanlık faaliyetinde bulunan her psikolojik danışman; somut bireysel yetenek, beceri ve niteliklerini en üst sınırında kullansa bile, ortalama özeni sağlayamadığı ölçüde kusurlu ve sorumludur (Gümüş, 2001; Başpınar, 2004). Ancak somut olayda bir psikolojik danışmanın sahip olduğu kuramsal bilgisi, yetenekleri, terapötik becerileri ortalama bir psikolojik danışmanın sahip olduğundan daha fazla ise; bu durum kendisini, ortalama psikolojik danışmanın özeninin ötesinde, sahip olduğu bilginin, yetenek ve becerilerin, eğitim düzeyinin ve meslek bilgisinin gerektirdiği daha yüksek özeni göstermeye zorunlu kılar (Gümüş, 2001). Dolayısıyla, "uzmanlık" veya "doktora” öğrenimiyle edinilen ünvanı kullanan bir psikolojik danışmanın göstereceği özen, lisans mezunu bir psikolojik danışmana göre daha fazla olacaktır. Buna karşılık psikolojik danışman kendi yetenek ve niteliklerini olandan daha yüksek (örneğin psikolojik danışman gerçekte olmamasina rağmen kendisini bir uzman veya doktora derecesine sahip psikolojik danışman olarak) göstermişse, kendisinden beklenecek özenin ölçüsü, ortalama bir psikolojik danışmanın ötesinde, uzman veya doktora derecesine sahip bir psikolojik danışmandan beklenecek olan daha yüksek özen ölçüsüne eştir. Mesleki uygulamada danışanlarca olağan olarak özenli nitelendirilen ortalamanın altındaki özensiz davranışlar, gerekli özen ölçüsünü ortadan kaldırmaz (Gümüş, 2001)

$\mathrm{Bu}$ çerçevede psikolojik danışman, eğitimini bitirdikten sonra, mesleki yayınları, kitapları, kongreleri takip ederek, mesleki bilgisini, psikolojik danışma alanındaki en güncel bilgiler ile yenilemekle yükümlüdür. Psikolojik danışmanın psikolojik danışma alanının genel kabul görmüş güncel kurallarına ilişkin bilgisizliği ve mesleki formasyon eksikliği, kendisini özensiz (Corey, Corey ve Callanan, 1998; Pope ve Vasquez, 2007) ve hukuksal olarak sorumlu kılar (Gümüş, 2001). Bir psikiyatristten farklı olarak psikolojik danışman, danışana ilişkin genel kabul gören psikiyatrik ölçütlere göre tanı koymakla yükümlü değildir. Ancak psikolojik danışman, problemi çözme bakımından "en uygun" ya da "amaca en iyi hizmet 
edecek" terapötik koşulları oluşturmak ve problemin çözümüne uygun yaklaşımı ve/veya teknikleri seçmek zorundadır (Pettermann, 2003). Psikolojik danışman psikolojik danışma ilişkisi boyunca, bir yaklaşıma bağlı kalabilir ya da eklektik bir yaklaşımı temel alabilir. Bu kapsamda psikolojik danışman, problemin çözümüne yardıma yönelik temel aldığı kuramsal yaklaşımın ve seçtiği tekniklerin gerektirdiği ilkelere ve uygulama biçimlerine göre, beklenen özen ölçütlerini yakalayarak psikolojik danışma sürecini yürüttüŭg̈ ölçüde; süreç sonunda danışanın problemi çözülmese bile, sözleşmeye uygun olarak sorumluluklarını yerine getirmiş olur. Ancak, psikolojik danı̧̧manın, verdiği psikolojik yardımın problemin çözümü için etkili olmayacağını bile bile, kendi gereksinimleri için ilişkiyi devam ettirmesi ve sağaltımın gerçekleşmemesiyle ilişkinin sonlanması psikolojik danışmanın hukuksal sorumluluğunu doğurur. Corey, Corey ve Callanan'a (1998) göre de psikolojik danışmanların danışanlarına zarar verecek özelliklerinin, çözülmemiş çatışmalarının ve gereksinimlerinin farkına varmaları, bunları kontrol etmeleri ve dürüst davranmaları danışanı uğrayacağı zararlardan korumak ve etkili yardım davranışlarıyla onu beslemek adına etik bir gerekliliktir.

Psikolojik danışman, aynı anda hepsini özenli olarak yürütebileceği sayıda danışanla, danışma ilişsisine girmesi de bu sorumluluk kapsamında değerlendirilir (Gümüş, 2001; Okun, 1987). Psikolojik danışman danışma sürecinin gereği gibi yürütülebilmesi için gerekli olan zamanı danışana ayırmak zorunda olup; yoğun iş yükü altında psikolojik danışma sürecini özenli olarak götürebilecek durumda olmadığını anlarsa PDS'yi derhal feshetmelidir. Aksi halde doğacak zararlardan sorumludur (Gümüş, 2001).

\section{b. Psikolojik danışman'ın psikolojik danışma sürecini kişisel olarak yürütme borcu:}

Psikolojik danışman ile yardım isteyen bir danışan arasında PDS kurulduğunda bu yardım sürecini psikolojik danışmanın bizzat kendisinin yürütmesi gerekir. BK m.390/III çerçevesinde "psikolojik danışman, danışanı ikinci bir psikolojik danışmana yönlendirmeye yetkili olduğu (1.olasılık) ya da şartlara göre başka bir psikolojik danışmana yönlendirmesinin zorunlu olduğu (2.olasılık) veya adet gereği uygun görüldüğü durumlar (3.olasılık) dışında psikolojik danışma ilişkisini kişisel olarak yürütmelidir".

Birinci olasıllğa göre, PDS kurulurken psikolojik danışman danışandan zaman zaman onu bir ikinci psikolojik danışmana yönlendirme yetkisini alması hukuka uygundur, ancak bu durum psikolojik danışma ilkelerine ve etik kurallarına uygun değildir. Üçüncü olasılık bakımından ACA'nın (2005) kabul ettiği gibi, psikolojik danışmanın tatile giderken ya da hastalandığı zaman danışanı acil durumlar için bir başka psikolojik danışmana yönlendirmesi uygun görülebilir. Psikolojik danışman daha çok ikinci olasılık kapsamında, danışanın probleminin tıbbi bir süreç olarak psikiyatrik tedaviyi gerektirdiğinde ya da kendi bilgi ve deneyiminin danışanın problemini çözmeye yetmeyeceğini fark ettiğinde, hatta yardım ilişkisinin danışana zarar verdiğini farkettiğinde danışanı daha yetkin bir psikolojik danışmana ya da uygun bir uzmana sevk etmek zorundadır. Özellikle psikolojik danışmanın intihar ve 
kendi kendine ya da başkalarının bedensel bütünlüğüne zarar verme eğilimi gösterdiği durumlarda, en kısa sürede danışanın psikiyatri kliniğine yatırılmasını sağlamak için gerekli girişimlerde bulunması gerekir (Deutsch ve Spickhoff, 2003). Burada psikolojik danışma ilişkisinin özelliği gereği, psikolojik danışman problemi çözmede yeterli olamayacağı için danışanı diğer bir uzmana sevk ederken, danışanla arasındaki PDS'yi de sahip olduğu fesih hakkını kullanarak (BK m.396) tek taraflı olarak sona erdirmelidir.

Psikolojik danışman, aralarındaki PDS'yi feshetmeksizin BK m.390/III'de öngörülen durumlardan biri olmadan danışanı "belirli bir" uzmana sevk etmişse, sevkettiği uzmanın fiillerinden kendi fiili gibi sorumlu olur (BK m.391/I). Buna karşıllk psikolojik danışman, aralarındaki PDS'yi feshetmeksizin BK m.390/III'de öngörülen durumlardan birine dayalı olarak, danışanı "belirli bir" uzmana sevk etmişse; sadece bu uzmanı seçmede ve ona talimat vermede özensiz davranmasından dolayı sorumlu olur (BK m.391/II).

Bunların yanında, grupla psikolojik danışma uygulamalarında da eğer psikolojik danışman oturumları bir yardımcı psikolojik danı̧̧manla birlikte yürütüyorsa, bu yardımcının grup üyelerine verdiği zarardan dolayı kusurlu olmasa bile BK m. 100'e göre psikolojik danışmanın yine kendisi sorumlu olur.

\section{c.Psikolojik danışmanın sadakat (dürüstlük) borcu:}

Sadakat yükümlülüğ̈̈, danışan ile psikolojik danışman arasındaki güven ilişkisine dayanır. Bu borç, psikolojik danışmanın danışanın çıkarlarını sözleşmenin amacı çerçevesinde koruyacağı ve davranışının danışanın çıkarına uygun olacağı yönündeki yükümlülüğünü ifade eder ve uygulamada özellikle, (1) psikolojik danışmanın danışanı aydınlatma (bilgilendirme) ve (2) psikolojik danışmanın gizliliği sağlama (sır saklama) borçlarında somutlaşır.

(1) Psikolojik danışmanın danışanı aydınlatma borcu: Psikolojik danışman, psikolojik danışma sürecine başlamadan önce ve başladıktan sonra süreç hakkında gerekli bilgiyi vererek danışana karşı aydınlatma yükümlülügünü yerine getirmelidir (Gümüş, 2001; Corey, 2001; Kitchener ve Anderson, 2000; Corey, Corey ve Callanan, 1998; Pope ve Vasquez, 2007).

Aydınlatma sonrası danışanın vereceği onay (rıza) psikolojik danışma sürecini, kendi psikolojik sağlı̆̆ı, vücut bütünlüğü ve özel yaşamı gibi kişisel değerlerine hizimet eden, hukuka uygun bir müdahale haline getirir. Ancak danışanın onayının danışmanın eylemini hukuka uygun hale getirebilmesi için danışanın neye onay verdiğini tam olarak bilmesi gerekir (Yavuz-İpekyüz, 2006; Büyükay, 2006; Ozanoğlu, 2003; Çilingiroğlu, 1993). Danışanın vereceği onay, ancak danışman tarafından "gerekli" olan bilgilendirme "yeterli" olarak yapılmışsa danışmanın yardım davranışlarını hukuka uygun hale getirir; yeterli aydınlatma yapılmaksızın alınan onay sonrası girilen psikolojik danışma sürecinde danışanın bir zarara uğraması halinde bu zarardan psikolojik danışman sorumludur (Çilingiroğlu, 1993; Ozanoğlu, 2003). Bu noktada psikolojik danışma hizmetleri için önemli bir kavram olan "aydınlatılmış onay (informed consent)" kavramı üzerinde durmak gerekir. 
Psikolojik danışma yardımını almak isteyen danışanların, sürece ilişkin yeterli bilgilendirilmeye gereksinimleri vardır. Bu yolla psikolojik danışma ilişkisine girip girmeme ya da ilişkiyi devam ettirip ettirmeme yönünde seçim hakların kullanırlar. Psikolojik danıșman hem kendinin hem de danıșanın sorumluluk ve haklarının sözel ve yazılı olarak danışanıyla birlikte gözden geçirip, üzerinde durma yükümlülükleri vardır. Hatta aydınlatılmış onay bütün psikolojik danışma sürecinin devam eden bir parçası olarak görülmesi ve psikolojik danışma iliş̧isi boyunca yapılan bu bilgi paylaşımının belgelendirilmesi gerekir (ACA, 2005; Pope ve Vasquez, 2007). Bu belgelendirmenin psikolojik danışmanların hazırladıkları aydınlatılımış onay formlarının imzalanmasıyla gerçekleştirilmesi en uygun yaklaşımdır (Meier ve Davis, 2006; Kitchener ve Anderson, 2000). Görüldüğü üzere danışanın aydınlatılmış onayının alınması, danışmanın danıșanın psikolojik bütünlüğüne yönelik müdahalesini hukuka uygun kılmanın bir gerekliliği olarak, PDS'den doğan yükümlülüklerinden biridir.

Buna göre psikolojik danışma ilişkisinin gerektirdiği biçimde yardım ilişkisinin amaçları, terapötik süreç, kuralları, sınırlııkları, yardımın bilinen risk ve yararları, danışan üzerindeki olası etkileri, gizliliğin, amacı ve sınırları, kayıtların nasıl ve hangi amaçla tutulacağı ve nasıl saklanacağı, psikolojik danışmanın ve danışanın rol ve sorumlulukları, psikolojik danışmanın nitelikleri, izlenecek yol ve kullanılacak teknikleri, alternatif yardım süreçlerinin neler olduğu, danışanın hakları, oturumların süresi, bütün sürecin tahmini süresi (Petermann, 2003; Kitchener ve Anderson, 2000; Corey, Corey ve Callanan, 1998; Pope ve Vasquez, 2007) ve psikolojik danışma sürecine danışanın aktif katılımının önemi belirtilerek yeterli bilgilendirme gerçekleştirilmelidir. $\mathrm{Bu}$ bilgilendirmede özellikle danışan için önem taşıyan "ekonomik bilgilendirme" üzerinde de durulmalıdır. Psikolojik danışman danışana psikolojik danışma sürecinin çoğu zaman uzun bir süreç olduğunu açıklamalı ve sürecin uzamasının danışana getireceği ekonomik yüke ilişkin bilgilendirmeyi doğru zamanda ve biçimde yapmalıdır (Pettermann, 2003). Yani psikolojik yardım süreci en başından itibaren açıklanamaz ve gizemli bir süreç olmaktan çıkarılıp, danışanın nasıl işlediğini kavrayabileceği bir süreç haline getirilmelidir. Bunu yaparken danışanın "anlayarak" verdiği onay önemli olduğu için psikolojik danışmanın danışanın anlama düzeyini kontrol etmesi ve danışanın seçme özgürlüğünü korumak için özenli davranması gerekir (Corey, Corey ve Callanan, 1998).

Aydınlatılmış onayın dört yasal yönü vardır: (1) Ehliyet (capacity): Danışanın akılcı karar verebilme yeterliği (ayırt etme gücü) ehliyet kavramı ile ifade edilir. Danışanın onay verme hakkı bütünüyle kendisine aittir. Danışanın ayırt etme gücünü kaybettiği her durumda, onun yerine yasal temsilci onay veremez. Yasal temsilcinin onay verebilmesi ancak, psikolojik danışma yardımının ayırt etme gücünü kaybetmiş danışanın sağaltımı için zorunlu ya da önemli olduğu durumlarda mümkün olur, hatta yasal temsilcinin bu onayı vermesi zorunludur. Aydınlatılmış onayın geçerliliğgi için aranan ayırt etme gücü için hukuksal bir yaş sınırı olmayıp, danışanın ayırt etme gücü her somut olay için ayrı ayrı değerlendirilir (Şenocak, 2001; Erman, 2003). Burada önem taşıyan nokta şudur: Ayırt etme gücüne sahip bir danışman danışma sürecine girmeye tek başına onay göstermesi sadece soyut danışma sürecini hukuka 
uygun kılmak için gereklidir. Bu nedenle söz konusu ayırt etme gücüne sahip danışan ergin değilse (kural olarak on sekiz yaşını tamamlamamışsa) tam ehliyetli sayılmayacağından, danışma sürecinin dayandığı PDS'nin geçerli olabilmesi için yine de yasal temsilcinin onayı aranacaktır. Yasal temsilcinin bu onayı aydınlatılmış onayın sağlanmasına yönelik olmayıp, PDS sözleşmesinin hukuken geçerli olmasına yöneliktir. (2) Bilgilendirmenin kapsamı: Psikolojik danışmanın danışana en açık biçimde bilgi verme ve bu bilginin anlaşıldığını kontrol etme sorumluluğu vardır. Geçerli bir onay verme, hem süreç hem de olası sonuçlarına ilişkin bilgilenmeyi, olası ters etkileri, riskleri ve uygulanabilir alternatif süreçleri içermelidir. (3) Gönüllülük: Danışanın karar verme sürecinde özgürce davranıyor olması, yasal ve psikolojik olarak onay verme yeterliğine sahip olması gerekir. Yine psikolojik danışmanlar ehliyeti olan danışanlarına (ancak mahkeme kararıyla tedavi ya da değerlendirmeye alınmamış olanlara) bu onayı herhangi bir nedenle ve herhangi bir zamanda geri alma haklarının olduğunu da açıklamalıdırlar (Şemin ve Aras, 2004; Corey, Corey ve Callanan, 1998; Pope ve Vasquez, 2007). (4) Yapılacak yardımın (müdahalenin) amacı: Aydınlatılmış onayın verildiği müdahale sağaltım amaçlı olmalıdır (Çilingiroğlu, 1993; Yavuz- İpekyüz, 2006). Bireyin psikolojik bütünlügünü bozan müdahale iyileştirme amacına hizmet etmiyorsa, en başında danışanın onayı alınsa bile, hukuka aykırıdır (TMK m.23).

(2) Psikolojik danışmanın gizliliği sağlama borcu: Psikolojik danışmanın öncelikli olan diğer bir yükümlülüğü de danışma sürecinin yaşamsal bir parçası olarak danışanın gizliliğini korumaktır (Corey, 2001; Pope ve Vasquez, 2007).

Psikolojik danışman, sadakat borcunun gereği olarak, psikolojik danışma süreci içerisinde danışana ait bilgileri, açıklamasını haklı gösteren bir hukuka uygunluk sebebi bulunmadıkça üçüncü kişilere karşı gizli tutmak zorundadır. Bu borç sadece gizli tutulmasında danışanın yararına olan ve açıklanması onun için maddi veya manevi zarara uğrama tehlikesi doğuracak olan bilgilere ilişkindir.

Gizliliğin hangi koşullarda bozulacağının danışana anlatılmasının terapötik ilişsinin kurulmasını engelleyici ya da zorlaştırıcı olduğunu savunan bazı uygulayıcılara rağmen, psikolojik danışman aydınlatılmış onayın alınması sırasında hangi durumlarda gizliliğin bozulacağının bilgisini de vermelidir (Kitchener ve Anderson, 2000).

Gizlilik, güvene dayalı ve üretken psikolojik danışma ilişkisinin gelişmesinde merkezi değere sahip hem yasal hem de etik bir konudur. Ancak danışanın kendisinin ya da diğerlerinin ciddi bir biçimde zarar görebileceği durumlarda gizlilik ilkesinin geçersiz kılınması gerektiği de açıktır. Çocukların istismarı, yaşlı olanların istismarı ve diğer insanların tehlikede olma durumu gizliliğin bozulmasını yasal olarak gerekli kilar (Corey, 2001).

Psikolojik danışmanın sır saklama yükümlülüğünün kapsamı, danışanın tercihlerine ya da sağlayacağı olası yararlara göre değişebilir. Örneğin, danışanın toplumsal konumu gereği bir psikolojik danışmana başvurduğunun bilinmesi maddi ve manevi istenmeyen sonuçlar doğuracaksa, psikolojik danışma ilişkisinin varlığının dahi gizli tutulması gerekir (Tandoğan, 1987; Petermann, 2003). 
Ancak psikolojik danışman, danışanın kendisine karşı açtı̆̆ davada kendisini savunmak için iddianın içeriğiyle sınırlı olacak biçimde danışanın sırlarını açıklayabilir (Ayan, 1991). Bunun dışında psikolojik danışmanlar, üçüncü kişilerce açılan davalarda Hukuk Usulü Muhakemeleri Kanunu m.245/b.4 uyarınca tanıklıktan çekilmek hakkına sahiptirler; ancak, danışanlarının onayı alınmışsa tanıklık yapmak zorundadırlar.

Danışanın belirli kişilere yönelmiş suç işleme yönündeki iradesini danışma süreci içerisinde öğrenen (örneğin, danışanın kardeşini öldürmek istediğini açıklaması) psikolojik danışmanın, kimliğini bildiği ve ulaşabildiği olası suç veya zararın yöneltileceği kişiye bu durumu bildirmesi gereklidir. Aksi takdirde danışman zarara uğrayacak kişiye karşı sorumludur (Öztürkler, 2006).

Psikolojik danışmanın sır saklama borcu gerek psikolojik danışma ilişkisi sırasında gerekse de psikolojik danışma ilişkisi sona erdikten sonra da devam eder.

Psikolojik danışmanın sır saklama yükümlülüğü, kendisinin cezai sorumluluğu bakımından da önem taşır:

1 Haziran 2005 tarihinde yürürlüğe giren 5237 sayılı Türk Ceza Kanunu meslek sırrının açıklanmasııı suç olmaktan çıkarmışısır. Ancak, TCK m.136, kişisel verileri, hukuka aykırı olarak bir başkasına veren, yayan veya ele geçiren kişileri, bir yıldan dört yıla kadar hapis cezası ile cezalandırmaktadır. Bu nedenle psikolojik danışmanın danışma sürecinde danışana ilişkin öğrendiği bilgiler kişisel veri niteliğini taşıdığından, söz konusu bilgileri hukuka aykırı olarak başkasına vermesi veya yayması, TCK m.136 uyarınca suç teşkil edecektir. Söz konusu suç, belli bir meslek ve sanatın sağladığı kolaylıktan yararlanmak suretiyle işlendiği için de TCK m.137 uyarınca verilen ceza yarı oranında artırılacaktır. Söz konusu suç şikayete bağlı bir suç değildir. TCK m.239, sıfat veya görevi, meslek veya sanatı gereği bildiği ticarî sır, bankacılık sırrı veya müşteri sırrı niteliğindeki bilgi veya belgeleri yetkisiz kişilere veren veya ifşa eden kişilerin, şikâyet üzerine, bir yıldan üç yıla kadar hapis ve beşbin güne kadar adlî para cezası ile cezalandırılacağını öngörmektedir. Ancak söz konusu kural ticari yaşamın dürüstlük kuralları çerçevesinde yürütülmesini amaçlayan bir düzenleme olduğundan (Arslan ve Azizağaoğlu, 2004), psikolojik danışmanlık faaliyetinin bir ticari işletme düzeyinde ticari bir organizasyona dayalı olarak yerine getirilmediği (örneğin bireysel olarak psikolojik danışmanlık faaliyeti yürütüldüğü) sürece, psikolojik danışmanca danışana ait bilgi ve belgelerin açıklanması sadece TCK m.136'daki suçu oluşturur. $\mathrm{Bu}$ nedenle TCK m.239'daki, suç ancak bir hastane veya bir ticari işletme düzeyindeki psikolojik danışma merkezlerinin danışana ait bilgi ve belgeleri açıklaması halinde oluşur.

TCK bazen psikolojik danışmanları danışanlara ilişsin bilgi ve verileri, yetkili makamlara açıklamakla ve bildirmekle yükümlü tutmakta; bilakis gerekli ihbar ve bildirimin yapılmamasını suç saymaktadır. Aşağıdaki hükümlere göre, psikolojik danışmanın danışana ilişsin üçüncü kişilere yapacağı bilgilendirme, "hukuka uygun" olacağından, TCK m.136'daki verileri hukuka aykırı olarak verme ve ele geçirme suçu oluşmayacaktır: 
TCK m.280/I'e göre görevini yaptığı sırada bir suçun işlendiği yönünde bir belirti ile karşılaşmasına rağmen, durumu yetkili makamlara bildirmeyen veya bu hususta gecikme gösteren sağlık mesleği mensubu, bir yıla kadar hapis cezası ile cezalandırılır. TCK m.280/II'ye göre ise, sağlık mesleği mensubu deyiminden tabip, diş tabibi, eczacı, ebe, hemşire ve sağlık hizmeti veren diğer kişiler anlaşılır. TCK m.280/II sağlık mesleği mensubu kavramını sınırlı sayıda saymadığından, bireyin psikolojik sağaltımına yönelik faaliyet gösteren psikolog ve psikolojik danışmanlar da, TCK m.280 anlamında sağlık memuru sayılır. Ancak TCK m.280/I'deki suçun faili, sadece kamu görevlisi sıfatına sahip olmayan sağlık görevlileri olabilir. Bu husus 280.maddenin gerekçesinde de belirtilmektedir. TCK m.280'e göre bildirilmesi gereken suçlar, kovuşturulması şikayete bağlı olmayan, yani kamu adına kovuşturulan suçlardır. Buna karşılık kamu görevlisi sıfatı olan sağlık mesleği mensubu göreviyle bağlantılı olarak işlendiğini öğrendiği bir suçu bildirmezse TCK m.279'daki suç oluşur (Donay ve Kaşıkçı, 2004). Sonuçta kamu görevlisi sıfatına sahip olmayan psikolojik danışmanların "danışma süreci sırasında veya danışma süreciyle bağlantılı olarak" bir suçun işlendiği yönünde bir belirtiyle karşılaşması ve dolayısıyla durumu yetkili makamlara bildirmemesi ya da bu bildirimde gecikme göstermesi TCK m.280/I'deki suçu oluşturur. Bu nedenle kamu görevlisi olmayan bir psikolojik danışman, örneğin danışma sürecinde danışanının aile üyelerinden birinin cinsel tacizine uğradığını, fiziksel işkencesine maruz kaldığını ya da danışanın bir kişiyi hukuka aykırı olarak evinde hapsettiğini öğrenirse, söz konusu suçları bildirmemesi TCK m.280'deki suç oluşur. Buna karşılık psikolojik danışman göreviyle bağlantılı olmayan bir şekilde -sonuçlarının sınırlandırılması mümkün olan- bir suçun işlendiğini öğrenirse ve bu suçu yetkili makamlara bildirmezse, psikolojik danışman olsun veya olmasın herkes için uygulanabilir bir hüküm olanTCK m. 278'deki suçu işlemiş olur.

TCK m.98'e göre ise, “yaşı, hastalığı veya yaralanması dolayısıyla ya da başka herhangi bir nedenle kendini idare edemeyecek durumda olan kimseye hâl ve koşulların elverdiği ölçüde yardım etmeyen ya da durumu derhâl ilgili makamlara bildirmeyen kişi, bir yıla kadar hapis veya adlî para cezası ile cezalandırılır (m.98/I). Yardım veya bildirim yükümlülüğünün yerine getirmeyene, kişinin ölmesi durumunda ise bir yıldan üç yıla kadar hapis cezası verilir (m.98/II). Dolayısıyla psikolojik danışman danışma sürecinde danışanının ileri yaşını, hastalığını (ağır psikolojik hastalığı dahil), yaralı olduğunu ya da başka herhangi bir nedenle kendini idare edemeyecek durumda olduğunu öğrenirse, durumu "en kısa sürede" ilgili makamlara bildirmek zorundadır. Gerekli bildirimin yapılmaması TCK m.98'deki suçu oluşturur. Ancak burada önemli olan nokta psikolojik danışmanın ilgili makamlara bildirimde bulunması için danışanın "kendisini yönetemeyecek, kendisini koruyucu kararlar alamayacak" bir durumda olmasının gerekmesidir. Örneğin danışanın intihar eğilimi varsa ve psikolojik danışman bu durumu ilgili makamlara bildirmemiş ve danışan da intihar edip ölmüşse, psikolojik danışman TCK m.98/II uyarınca daha ağır cezaya çarptırılır.

Psikolojik danışmanın yukarıdaki suçları mesleğinin sağladığı hak ve yetkileri kötüye kullanmak suretiyle veya sürecin gerektirdiği dikkat ve özen yükümlülüğüne 
aykırı davranarak işlemiş olması durumunda, TCK m.50/1, bend e. uyarınca hakim, psikolojik danışmanın mahkum olduğu bir yıl veya daha az olan hapis cezası "yerine", verilen cezanın yarısından bir katına kadar süreyle, psikolojik danışma mesleğini yapmaktan yasaklanmasına karar verebilir.

Sonuçta psikolojik danışmanın yukarıdaki Türk Ceza Kanunu maddeleri kapsamında ilgili makamlara bildirim ve ihbarda bulunması, ilgili hükümlerin bir hukuka uygunluk sebebi oluşturması nedeniyle sır saklama yükümlülüğünün ihlalinden dolayı psikolojik danışmanı danışana karşı tazminat ödemekle sorumlu k1lmaz.

d. Psikolojik danışmanın danışana ve psikolojik danışma oturumlarına ilişkin kayıt tutma ve bu kayıtları saklama borcu:

Psikolojik danışman, hukuksal olarak psikolojik danışma sürecinde danışana ilişkin edindiği bilgileri ve psikolojik danışma sürecini ilk oturumdan sonuncusuna kadar kayda geçirmek ve gizliliğini koruyarak saklamakla yükümlüdür (Ayan, 1991; Yavuz-İpekyüz, 2006).

Psikolojik danışma sürecinde tutulması gereken kayıtlar en azından, danışanın kimlik bilgilerini; psikolojik durumunu anlatan ölçüm ve değerlendirme sonuçlarını; psikolojik testlerden elde edilmiş önceki ve şimdiki sonuçları; imzalanmış aydınlatılmıs onay formunu; sağaltım planını; belli hedef problem ve bunlara bağlı yardım sürecinin amaçlarını; danışanın ifade ettiği problemlerini; eğer yapıldıysa başka bir uzmana sevk edildiğine ilişkin belgeyi, ilerleme kayıtlarını, verilen yardımın türünü, görüşmelerin kesin tarih ve saatinin belirtildiği oturum özetlerini içermelidir (Corey, Corey ve Callanan, 1998; Pope ve Vasquez, 2007).

Psikolojik danışmanlar elektronik ya da diğer yollarla ses ya da görüntü kaydı alamaya başlamadan önce danışanlarından izin almaları ve danışanlarına süreçle ilgili olarak tuttukları bütün kayıtların güvenli bir yerde saklanacağına ve sadece yetkisi olan kişilerce bu bilgilere ulaşabileceğine dair güvence vermeleri gerekir (ACA, 2005). TCK m.133 uyarınca da psikolojik danışman danışan ile arasında geçen konuşmaları danışanın rızası olmaksızın bir ses alma cihazı ile kaydetmesi halinde, iki aydan altı aya kadar hapis cezası ile cezalandırılır. Söz konusu suç psikolojik danışmanlık mesleğinin sağladığı kolaylıktan yararlanılarak işlendiği için verilecek ceza takdire bağlı olmaksızın hakim tarafindan yarı oranında artırılır (TCK m.137)

Psikolojik danışma sürecinin tam ve düzenli olarak kayıtlarının tutulması iki amaca hizmet eder: (1) danışana olabilecek en iyi yardımı verebilmek ve (2) kötü uygulamaya maruz kalmış olma iddialarının konu olduğu davalarda psikolojik yardım verenlerin güvenliği için temel oluşturmak. Dolayısıyla kayıt tutmadaki yetersizlik, psikolojik danışmanların kendilerini yasal ve etik tehlikeye sokmaları anlamını taşır ki bu büyük bir hatadır. Psikolojik danışmanlar tam ve düzenli not tutmamalarının nedenleri olarak, yeterli zamanlarının olmamasını, psikolojik danışma uygulamalarının hukuki bir davanın konusu olabileceğini akıllarına getirmek istemeyişlerini, kayıt tutmaları durumunda gizliliğin bozulacağından kayg duyduklarını ve kayda gerek kalmadan danışanın ne söylediğini anımsayabileceklerine inandıklarını ileri sürerler (Corey, Corey ve Callanan, 1998). 
Kayıt tutma psikolojik danışma sürecinin özenli olarak takip ve yönetimi bakımından da büyük önem taşır. Psikolojik danışman görüşmeye girmeden önce yapılmış görüşmelere ilişkin kaydedilmiş bilgileri okumak, oturumların ve danışanın gelişim seyrini izlemek ve gelecek psikolojik danışma oturumlarının geçici planını oluşturmak için bu kayıtlara başvurmak durumundadır (Tan, 1992). Psikolojik danışman, psikolojik danışma sürecinin gerekli kayıtlarını tutmaması nedeniyle danışanın uğradığı zararlardan sorumlu olduğu gibi, psikolojik danışma sürecinin bu nedenle uzadığı hallerde danışanın ücret indirimi talebini karşılamak zorundadır. Ayrıca psikolojik danışman, tutulması gerekli olan bu kayıtların gizliliğini sağlamak bakımından da her türlü önlemi almakla yükümlüdür.

\section{e. Psikolojik danışmanın danışanın bütünlük menfaatini koruma borcu:}

Psikolojik danışmanın öncelikli sorumluluğu danışanın iyilik halini desteklemek ve ona saygı duymaktır. Bunların yanında danışanlarına zarar verici biçimde davranmaktan kaçınmak, öngörülemez ya da kaçınılmaz zararları en aza indirmek ya da çaresini bulmak da psikolojik danışmanların öncelikli sorumlulukları arasinda yer alır (ACA, 2005).

Psikolojik danışman hukuksal olarak danışanın probleminin çözümüne yönelik iyilik halini desteklemek dişında malvarlığı ve kişisel değerlerine (örneğin, vücut bütünlüğüne) de sayg1 göstermek ve zarar vermemekle yükümlüdür. Bu borç psikolojik danışmanın danışana "saygı duyma" borcu olarak da adlandırılır (Deutsch ve Spickhoff, 2003). Bu nedenle, psikolojik danışmanın danışan ile duygusal veya cinsel yakınlığa girmesi psikolojik danışmanın saygı borcunun ihlalini oluşturur ve danışanın bu yakınlaşma nedeniyle uğrayacağı zararlardan psikolojik danışmanı sorumlu kılar. Aynı şekilde psikolojik danışmanın danışana tecavüz etmesi, dövmesi kadar; danışan üzerindeki etkisini kullanarak danışanın maliki olduğu malları üzerine geçirmesi, eşyalarını hediye etmeye teşvik etmesi biçiminde danışanı ekonomik olarak sömürmesi de, kendisini hukuksal olarak sorumlu kılar. Bu durumların yanında danışanın zayıflığından yararlanarak, danışmanın psikolojik danışma ilişkisini gereksiz yere uzatarak, uzun süreli para alması sözleşmeye aykırı olarak danışana zarar verme anlamı taşır (Ayan, 1993; Gümüş, 2001; Yavuz İpekyüz, 2006). Bu kapsamda danışmanın danışanın eşi veya cinsel partneri ile ilişki kurması dahi sözleşme ihlalini oluşturur (Öztürkler, 2006).

\section{Danışanın Borçları}

\section{a. Danışanın ücret ödeme borcu:}

BK 386/III'e göre, vekalet sözleşmesi niteliğindeki bir PDS'de danışan, sözleşmede kararlaştırılmışsa veya adettense psikolojik danışmana ücret ödemek zorundadır. Ancak psikolojik danışmanlık hizmetinin profesyonel bir serbest meslek faaliyeti olarak verildiği her durumda ücret adetten sayılır (Gümüş, 2001) ve danışan psikolojik danışmana, PDS'nin açıkça ücretsiz olduğu kararlaştırılmadıkça ücret ödemek zorundadır. 
Psikolojik danışmanın psikolojik danışma sürecinde özenli davranmadığı durumlarda danışan bir zarara uğramışsa, zararının tazminini isteyebilir; bir zarara uğramamışsa psikolojik danışmandan bu kez ücret indirimi (ödenen ücretin kısmen iadesi) isteğinde bulunabilir (Gümüş, 2001; Yalçınduran, 2004).

Danışan ve psikolojik danışmanın PDS'yi ücretsiz olarak akdetmeleri, psikolojik danışmanın özen borcunu hafifletmez, ancak doğan zararlar bakımından danışana ödenecek tazminat tutarında indirim sebebi olarak dikkate alınır (Gümüsş, 2001).

Psikolojik danışman ve danışan bir ücret ödenmesini kararlaştırmış fakat tutarını belirlememişlerse, psikolojik danışma sürecinin gerektirdiği uzmanlık derecesi, harcanan emek, zaman ve benzer işlerde verilmesi adetten olan ücret miktarı üzerinden ücret tutarı belirlenir (Yavuz, 2002). ACA (2005) ve Türk PDRDER'in (2006) yayınladığı etik kurallara göre, ücret belirlenirken hem danışanların parasal durumu hem de bulunulan yörede bu tür hizmetlere uygulanan ücretler ölçüt alınır; ayrıca ücret ödeyemeyecek durumdaki danışanların ücretsiz ya da çok az ücretle yardım alabilecekleri sosyal yardım ya da kamu kuruluşlarına gitmelerine yardımc1 olunması gerekir.

\section{b. Danışanın psikolojik danışmanın bütünlük menfaatini koruma borcu:}

Danışan psikolojik danışmanın ücret menfaati dışındaki diğer malvarlığına ve kişisel değerlerine de saygı göstermek ve zarar vermemekle yükümlüdür. Örneğin danışanın psikolojik danışmana karşı şiddet uygulaması, psikolojik danışmanın eşyalarına zarar vermesi danışanı da psikolojik danışmana karşı sorumlu kılar. Özellikle bir kişisel değer olarak psikolojik danışmanın özel hayat alanının korunması bakımından, danışan psikolojik danışmanı, psikolojik danışma oturumları dışında haklı sebep ve durumlar dışında, olmadık zamanlarda ve olmadık sebeplerle telefonla ya da yüz yüze rahatsız etmemekle yükümlüdür.

Psikolojik Danışmanın Psikolojik Danıșma Sözleșmesinden Doğan Borçlarını Kusurlu Olarak Hiç veya Gereği Gibi Yerine Getirmemesi Durumunda Tazmin Etmesi Gereken Zarar

Psikolojik danışman, PDS'den doğan borçlarını kusurlu ihlali nedeniyle danışanın uğradığı zararlardan sorumludur.

Danışan öncelikle maddi zararın tazminini talep edebilir. Maddi zarar, danışanın malvarlığına ilişkin zarar olarak yeniden tedavi masrafları, yoksun kalınan kârı ve kişiye ilişkin zarar olarak da danışanın geçici veya sürekli olarak çalışma gücünün kaybından doğan zararları kapsar (Oğuzman ve Öz, 2005; Eren, 2006; Öztürkler, 2006).

Psikolojik danışman ayrıca kusurlu sözleşme ihlali nedeniyle danışanın kişilik değerlerindeki eksilme nedeniyle duyduğu acı ve üzüntüye karşılık danışana uygun bir manevi tazminat ödemekle de yükümlüdür (BK m. 47). Psikolojik danışmanın danışana yönelik borçlarını kusurlu olarak hiç veya gereği gibi yerine getirmemesi nedeniyle, danışanın eşi, çocukları veya diğer "yakınları", eș ve çocuk sevgisi, aile 
bağları gibi sahip oldukları kişisel değerlerindeki eksilmeye bağlı duydukları acı nedeniyle, PDS'ye taraf olmasalar bile psikolojik danışmandan manevi tazminat talebinde bulunabilirler (BK m.49).

\section{Psikolojik Danışma Sözleşmesinin Sona Ermesi}

PDS, danışan ve psikolojik danışman arasındaki özel güven ilişkisine dayanır. Söz konusu güven ilişkisinin onarılmaz biçimde bozulmasıyla, psikolojik danışma ilişkisinin sona erdirilmesi bir zorunluluktur (Pattermann, 2003). Danışan veya psikolojik danışmandan birinin kendi eylemleriyle borç altına girebilme ve hak sahibi olma (fiil) ehliyetini kaybetmesi (örneğin, taraflardan birinin ayırt etme gücünü kaybetmesine yol açacak bir akıl hastalığına yakalanması) veya iflas etmesi de, PDS sözleşmesini kendiliğinden sona erdirecektir (BK m.397). Ayrıca, ortada haklı bir sebep varsa (örneğin danışan psikolojik danışmana fiziksel bir saldırıda ya da cinsel tacizde bulunmuşsa) uygun olmayan bir zamanda da psikolojik danışman PDS'yi sonlandırabilir ve bu sonlanmadan doğan danışanın zararlarından sorumlu tutulamaz.

Bu kapsamda gerek danışan gerekse de psikolojik danışman ortada haklı bir sebep olsun veya olmasın mevcut PDS'yi her zaman için diğerine yönelteceği tek taraflı irade beyanıyla ileriye dönük sona erdirebilir (feshedebilir) (Gümüş, 2001; Pattermann, 2003; Sarı, 2004). Ancak, gerek danışan gerekse psikolojik danışman fesih hakkını uygun bir zamanda kullanmazlarsa, bu sonlanmadan dolayı karşı tarafın uğradığı zararı tazmin etmekle yükümlüdürler (BK 396/I-II). Bununla birlikte PDS'ye dayalı psikolojik yardım ilişkilerinin uygun olmayan zamanda sona erdirilmesi durumunda zarar gören taraf olayların tamamına yakınında danışan olacağından, uygun olmayan zamanda sözleşmeyi fesh eden psikolojik danışmanın danışanın zararını tazmin yükümlülüğünden bahsedilmesi daha uygundur.

Fesih ileriye dönük etkili olduğu için, fesih tarihine kadar özenli olarak danışma ilişkisini yürüten psikolojik danışmana ödenen ücretin iadesi danışan tarafindan istenemez; ancak psikolojik danışmanın fesih tarihine kadar özensiz iş görmesi durumunda, danışanın bundan dolayı bir zarara uğrarsa tazminat, zarara uğramazsa ödediği ücrette indirim (kısmi ücret iadesi) isteme hakkı saklıdır.

Fesih bildirimi geçerliliği bakımından bir şekle bağlı olmasa bile, ispat kolaylığı bakımından yazılı yapılmalıdır. Bu çerçevede fesih bildiriminde bulunan tarafın karşı taraftan bu beyanın kendisine ulaştığına dair imzalı bir belge alması yerinde olur.

Ancak yine de bilinmelidir ki, psikolojik danışmanların danışana tazminat ödemeyi göze alarak, uygun olmayan bir zamanda PDS'yi sona erdirmeleri hukuksal olarak olanaklı olsa bile, bu sonuç ACA'nın (2005) belirlediği etik kurallara uygun değildir. Bu kurallara göre uygun sonlanma koşulları (psikolojik danışmanın yetersizliği, hastalığı, danışanın artık yardıma ihtiyacı olmaması ya da yardım ilişkisini sonlandırmak istemesi gibi) oluşmadıkça psikolojik danışmanlar devam eden yardım ilişkisini kesmemelidirler. 


\section{Tüzel Kişiliğe Sahip Psikolojik Danışma Merkezlerinin Sorumluluğu}

Günümüzde psikolojik danışma hizmetleri, bireysel mesleki faaliyetlerin ötesinde çoğu zaman tüzel kişiliğe sahip bir "Psikolojik Danışma Merkezi" bünyesinde çalışan psikolojik danışmanlarca verilmektedir. Danışan çoğu zaman tüzel kişiliğe sahip bir psikolojik danışma merkezine başvurur ve onunla bir PDS kurar. Bu sözleşmeye dayalı psikolojik danışma süreci danışan ile merkezde "hizmet sözleşmesiyle" çalışan bir psikolojik danışman arasında yürütülür. Bu durumda psikolojik danışman, BK m.100 anlamında PDS sözleşmesinin tarafi olan psikolojik danışma merkezinin borcunu yerine getirmede (ifa) kullandığı bir "ifa yardımcısı" konumundadır. Bunun sonucu olarak danışan ile psikolojik danışman arasında bir sözleşme kurulmaz; danışanın, psikolojik danışmanın yardım sürecindeki "kusurlu" davranışları nedeniyle zarara uğradığı hallerde, psikolojik danışman PDS'ye göre değil, haksız fiil hükümlerine (BK m. 41 vd.) göre tazminat ödemekle yükümlüdür. Buna karşılık psikolojik danışma merkezi, PDS'nin ifasında ifa yardımcısı (danışman) kullanması nedeniyle, PDS'ye göre "kusursuz olarak" sorumludur (BK m.100) (Ayan, 1991; Akkanat, 2006). Sonuçta danışanın, hem psikolojik danışmana haksız fiil sorumluluğu nedeniyle, hem de psikolojik danışma merkezine sözleşmeye dayalı sorumluluğu nedeniyle tazminat davası açabilmesi mümkündür. Ancak davalılardan birinin yapacağı tazminat ödemesiyle diğeri, danışana karşı borcundan kurtulmuş olur. Bundan farklı olarak psikolojik danışman, bir psikolojik danışma merkezine ait mekanı psikolojik danışma merkezinin bir çalışanı olmaksızın kendi danışanları ile olan görüşmeleri için kullanıyorsa; psikolojik danışman ifa yardımcısı konumunda olmadığından, psikolojik danışma merkezinin danışanın uğrayacağı zararlardan dolayı kusursuz sorumluluğu dahi yoktur; sorumluluk sadece PDS'ye dayalı olarak psikolojik danışmana aittir (Akkanat, 2006).

\section{SONUÇ VE ÖNERILER}

Bu makalede "özel” psikolojik danışma hizmetlerinde danışmanla danışan arasındaki psikolojik yardım ilişkisinin hukuksal boyutu ve psikolojik danışmanın özel hukuktan doğan hukuksal sorumluluğu ele alınmıştır.

Ülkemiz koşulları içinde gelişimini devam ettirmekte olan psikolojik danışma ve rehberlik hizmet alanının meslekleşmesi yolunda aşması gereken en önemli sorun; bu hizmetin bir kamu kurumu niteliğinde meslek kuruluşu (meslek birliği) çatısı altında yürütülmesinin sağlanması ve meslek birliği tarafından etik kuralların belirlenerek yasa kaynaklı mesleki yaptırımlara kavuşturulmasıdır. Ancak mesleki yaptırımları uygulayacak meslek birliklerinin henüz oluşturulmamasına bağlı olarak, psikolojik danışmanlar mesleki etik kuralları ihlal etmeleri durumunda mesleki yaptırımlara uğramasalar bile, danışanla akdettikleri ve temelde bir vekalet sözleşmesi niteliğindeki (BK m.386-398) psikolojik danışma sözleşmesi (PDS) çerçevesinde danışana karşı hukuken sorumludurlar.

Psikolojik danışmanın danışana karşı PDS'den doğan başlıca borçları şunlardır: Danışanın problemlerini çözmeye yönelik olarak psikolojik danışma sürecini “özenli” olarak yürütme borcu; psikolojik danışma sürecini kişisel olarak yürütme 
borcu; danışana sadakat borcu; danışanı aydınlatma borcu; gizliliği sağlama borcu; danışma oturumlarına ilişkin kayıt tutma ve bu kayıtları saklama borcu ve danışanın bütünlük menfaatini koruma borcu. Danışanın psikolojik danışmana karşı olan borçları ise ücret ödeme ve psikolojik danışmanın bütünlük menfaatini korumadır. Danışman, PDS'den doğan borçlarını kusurlu ihlali nedeniyle danışanın uğradığı maddi ve manevi zararları tazmin etmekle yükümlüdür.

Gerek danışan gerekse de psikolojik danışman ortada haklı bir sebep olsun veya olmasın mevcut PDS'yi her zaman için diğerine yönelteceği tek taraflı irade beyanıyla ileriye etkili olarak sona erdirebilir (feshedebilir); ancak, psikolojik danışmanın fesih hakkını uygun bir zamanda kullanması zorunlu olup, uygun olmayan zamanda sözleşmeyi feshettiğinde danışanın uğradığı zararı tazmin etmekle yükümlüdür.

Psikolojik danışma yardımı tüzel kişiliğe sahip bir "Psikolojik Danışma Merkezi" bünyesinde çalışan psikolojik danışmanlarca veriliyorsa, psikolojik danışman, PDS sözleşmesinin tarafi olan psikolojik danışma merkezinin borcunu yerine getirmede (ifa) kullandığı bir "ifa yardımcısı" konumunda olup danışanın borca aykırı davranışlarından psikolojik danışma merkezinin kusuru olmasa dahi sorumludur; psikolojik danışman ise yardım sürecindeki "kusurlu" davranışları nedeniyle verdiği zararlardan dolayı PDS'ye göre değil, haksız fiil hükümleri uyarınca sorumlu olur.

$\mathrm{Bu}$ çalışma psikolojik danışmanların sözleşmeye dayalı hukuksal sorumluluklarına ilişkin olmasına rağmen, sır saklama yükümlülükleri psikolojik danışmanlar için önemli olduğu için ayrıca, TCK'nun m.50, m. 98, m.133, m.136137, m.239, m.278 ve m. 280 çerçevesinde ele alınmıştır.

Ayrıca psikolojik danışma ve rehberlik alanı için belirlenmiş olan etik kurallar (Türk PDR-DER, 2006) ile bu çalışmanın inceleme konusu olan psikolojik danışmanların danışanlara karşı olan hukuksal sorumlulukları aşağıdaki gibi karşılaştırılmış ve etik kuralların çok büyük bir kısmının yasalarla da desteklendiği görülmüştür:

- Psikolojik danışmanın danışanın problemlerini çözmeye yönelik "özenli" olarak etkinlikte bulunma borcu, etik kurallarda "Genel Standartlar" başlı̆g 1 altında "a. Yetkinlik sınırları alt başlığının 1. ve 2. maddesinde" (s.9-10) ve "b. Uzmanlıkta Sürekli Gelişme" (s.10) alt başlı̆ıında karşılığını bulur.

- Psikolojik danışmanın danışma sürecini kişisel olarak yürütme borcu, etik kurallarda "Genel Standartlar" başlı̆̆ altında "f. Başkalarına Zarar Vermemek" alt başlığında (s.11) ve "Psikolojik Danışma İlişkileri" başlığı altındaki 13. maddelerinde (s.13) karşllığını bulur.

- Psikolojik danışmanın danışanı bilgilendirme borcu, etik kurallarda "Psikolojik Danışma İlişkileri” başlığı altındaki 1. 2., 9., 17. ve 21. maddelerinde (s.12-15) karşılı̆̆ıı bulur.

- Psikolojik danışmanın gizliliği sağlama borcu, etik kurallarda "Genel Standartlar" başlığı altında "g. Gizli Bilgiler" alt başlığında (s.11) ve 
"Psikolojik Danışma İlişkileri” başlığı altındaki 4., 6., 7., 8. ve 20. maddelerinde (s.12-15) karşılığını bulur.

- Psikolojik danışmanın danışanın bütünlük menfaatini koruma borcu, etik kurallarda "Genel Standartlar" başlığı altında "d.Ücret alt başlığının 1., 2. ve 3. maddesinde (s.10-11); aynı başlığın "e. Duygusal ve Cinsel Taciz" alt başlığının 1. ve 2. maddesinde (s.11) ve "Psikolojik Danışma İlişkileri" başlığı altındaki 3., 11. ve 16. maddelerinde (s.12-14) karşılığını bulur.

Danışanların psikolojik danışmanlara yönelik borçları bakımından,

- Danışanın ücret ödeme borcu etik kurallarda, “Genel Standartlar” başlığ altında "d.Ücret alt başlığının 1. ve 2. maddelerinde (s.10) karşılığını bulur.

- Danışanın psikolojik danışmanın bütünlük menfaatini koruma borcu ise etik kurallarda "Psikolojik Danışma İlişkileri" başlığı altındaki 6. ve 10 . maddelerinde (s.13) karşılığını bulur.

$\mathrm{Bu}$ çalışmanın sonuçlarına dayanarak şu önerilerde bulunulabilir:

1. Psikolojik danışma ve rehberlik ve diğer psikolojik yardım meslekleri için tüzel kişiliğe sahip bir meslek birliğinin (meslek odası) kurulmasının dayanağını oluşturacak yasanın TBMM tarafindan kabulünü sağlamaya yönelik çalışmalara hız kazandırılmalıdır.

2. Hukukun temel ilkelerinden biri de "kanunu bilmemek mazeret sayılmaz" ilkesidir. Buna göre bir hukuk kuralı yürürlüğe girdiği andan itibaren bilinsin ya da bilinmesin herkes için bağlayıcıdır. Dolayısıyla bu çalışmanın işaret ettiği Borçlar Kanunu ve genel çizgileriyle Ceza Kanunu hükümlerine göre psikolojik danışmanların danışanlara karşı hukuksal sorumlulukları lisans ve lisansüstü eğitim aşamalarında etik kuralların yanında inceleme konusu yapılmalı ve meslek elemanlarının yeterli düzeyde bilgilendirilmesi üzerinde titizlikle durulmalıdır.

3. İlgili meslek dernekleri tarafindan, psikolojik yardım almaya gelen bireylere karşı uzmanların (psikolojik danışmanların, psikologların ve psikiyatristlerin) hukuksal sorumluluğuna ilişkin bilgilendirme çalışmaları, basın ve yayın organları aracılığıyla yerine getirilmelidir.

4. Psikolojik danışma ilişkisi başlatılırken PDS'nin hatta danışanlardan alınması gereken aydınlatılmış onayın içeriğine ilişkin örnekler meslek dernekleri tarafından hazırlanıp psikolojik danışmanların kullanımına sunulmalıdır.

5. Bu çalışmanın işaret ettiği hukuksal sorumluluklar da dikkate alınarak, mesleki etik kurallar yeniden gözden geçirilmeli ve daha sık revizyonu yapılmalıdır.

6. Psikolojik danışmanların etik kurallara ve hukuksal sorumluluklara ilişkin tutumlarına yönelik araştırmaların yapılması özendirilmelidir.

7. Her ulusal psikolojik danışma ve rehberlik kongresinde "psikolojik danışma ve rehberlik mesleğinde etik ve yasa" konulu oturumlara yer verilmeli; akademisyen ve uygulayıcıların bu oturumlara katılımları özendirilmelidir. 


\section{KAYNAKLAR}

American Counseling Association (ACA). (2005). ACA Code of ethics. (Elektronic version).

Acar, N.V. (2003). "Danışma psikolojisiyle hukukun meslek kuralları açısından karşılaş̧ırılması". PDR'de yirmibeşy yll (Makaleler). Ankara: Nobel Yayıncılık.

Akkanat, H. (2006). Hastaneye kabul sözleşmesinin görünüm tarzları ve sorumluluk düzeni. Prof.Dr. Özer Seliçi'ye Armağan. Ankara: Seçkin Yayıncılık.

Arslan, Ç. ve Azizağaoğlu, B. (2004). Yeni Türk Ceza Kanunu Şerhi. Ankara: Asil Yayın Dağıtım Ltd.

Ayan, M. (1991). Tıbbî müdahaleden doğan hukukî sorumluluk. Ankara: Kazancı Kitap Tic.

Başpınar, V. (2004). Vekilin (avukatın, hekimin, mimarın, bankanın) özen borcundan doğan sorumluluğu (2. Baskı). Ankara: Yetkin Yayınları.

Bersoff, D.N. (2000). Ethical conflicts in psychology. (2. Edition). Washington D.C.: American Psychological Assosiation.

Büyükay, Y. (2006). İstenmeden dünyaya gelen çocukların bakım eğitim ve tedavi giderlerinin tazmin edilmesi sorunu. İstanbul: Vedat Kitapçılık.

Corey, G., Corey, M.S. ve Callanan, P. (1998). Issues and ethics in the helping proffesions. (5th ed.). Pacific Grove, CA: Brooks/Cole.

Corey, G. (2001). Theory and practice of counseling and psychotherapy. (6th Ed.). PacificGrove, CA: Brooks/Cole.

Çilingiroğlu, C. (1993). Tıbbi müdahaleye rıza. İstanbul: Filiz Kitabevi.

Deutch, E. ve Spickhoff, A. (2003). Medizinrecht. Arztrecht, arzneimittelrecht, medizineproducterecht und transfusionsrecht. Berlin: Springer.

Doğan, S. ve Ergüner-Tekinalp, B. (2002). Lisans düzeyinde "meslek sorunları ve ahlak ilkeleri" dersinin kapsam ve işlenişi: Gazi Üniversitesi örneği. Psikolojik danışmanlıkta etik sempozyumu kitapçı̆̆ı. YÖRET, (8-9 Haziran), 22-32.

Donay, S. ve Kaşıkçı, M.(2004). Açıklamalı karşılaşttrmalı gerekçeli Türk Ceza Kanunu. İstanbul: Beta.

Eren, F. (2006). Borçlar hukuku genel hükümler. İstanbul: Beta.

Erman, B. (2003). Ceza hukukunda tıbbi müdahalenin hukuka uygunluğu. Ankara: Seçkin.

Gümüş, M. A. (2001). Türk-İsviçre borçlar hukukunda vekilin özen borcu. İstanbul: Beta Basım Yayın Dağıtım.

Kitchener, K.S. ve Anderson, S.K. (2000). Ethical issues in counselig psychology: Old themes-newproblems. Handbook of counselig psychology. (3th ed.) (Ed.: Brown, S.,D. \& Lent, R.W.). New York: John Wiley \& Sons, Inc.

Meier, S.T. ve Davis, S.R. (2006). Psikolojik danışma. Temel öğeler. (Çev. Doğan, S. Bektaş, D.Y., Kocabaş, E.Ö., Denizli, S.). Ankara: Pegem-A Yayıncılık. 
Oğuzman, M.K. ve Öz, T. (2005). Borçlar hukuku genel hükümler. İstanbul: Filiz Kitabevi.

Okun, B.F. (1987). Effective helping. Interviewing and counseling techniques. (3. Edition).Montery: Brooks/Cole Pub. Com.

Ozanoğlu, H. S. (2003). Hekimlerin hastalarını aydınlatma yükümlülüğü. Ankara Üniversitesi Hukuk Fakültesi Dergisi, 52 (3), 76-92.

Özdemir, H. (2004). Özel hukukta teşhis ve tedavi sözleşmesi. Ankara: Yetkin Yayınları.

Öztürkler, C. (2006). Hukuk uygulamasında tıbbi sorumluluk, teşhis, tedavi ve tıbbi müdahaleden doğan tazminat davalart. Ankara: Seçkin.

Patterson, L.E. ve Eisenberg, S. (1983). The counseling process. Boston: Houghton Mifflin Comp.

Petermann, F. (2003). Der psychotherapeuten-vertrag- im spannungsfeld von übertragung,gegenübertragung und realität. AJA / PJA. 1291-1315.

Pope, K.S. ve Vasquez, M.J.T. (2007). Ethics in pyschotherapy and counseling. A practical guide (3. Ed.) San Francisco: John Willey \& Sons. Inc.

Sarı, S. (2004). Vekalet sözleşmesinin tek taraflı olarak sona erdirilmesi. İstanbul:Beşir Kitabevi.

Sungurtekin-Özkan, M. (1999). Avukatllk mesleği avukatın hak ve yükümlülükleri. (2.Bask1). İzmir: Barış Yayınları Fakülteler Kitabevi.

Şemin, S. ve Aras, Ş. (2004). Psikiyatride etik. İzmir: Dokuz Eylül Yayınları.

Şenocak, Z. (2001). Küçüğün tıbbî müdahaleye rızası. Ankara Üniversitesi Hukuk Fakültesi Dergisi, 4, 65-80.

Tan, H. (1992). Psikolojik yardim ilişskileri. Danışma ve psikoterapi. İstanbul: Milli Eğitim Bakanlığı Yayınları.

Tandoğan, H. (1987). Borçlar hukuku özel borç iliş̧kileri, c.II, 3.B., Ankara: Banka ve Ticaret Hukuku Araştırma Enstitüsü.

Türk Psikolojik Danışma ve Rehberlik Derneği (Türk PDR-DER). (1995). Psikolojik danışma ve rehberlik alanında çalışanlar için etik kurallar. Ankara.

Türk Psikolojik Danışma ve Rehberlik Derneği (Türk PDR-DER). (2006). Psikolojik danışma ve rehberlik alanında çallşanlar için etik kurallar. Ankara.

Yavuz, C. (2002). Türk borçlar hukuku özel hükümler. (6.Bask1). İstanbul: Beta.

Yavuz İpekyüz, F. (2006). Türk hukukunda hekimlik sözleşmesi. İstanbul: Vedat Kitapçllik.

Yalçınduran, T. (2004). Vekalet sözleşmesinde ücret. Ankara: Yetkin Yayınları. 